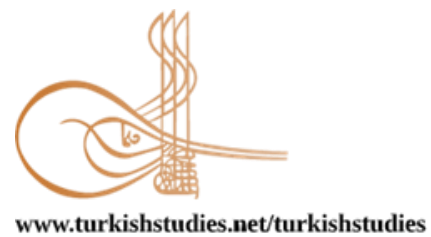

Turkish Studies

\title{
Covid-19 Pandemi (Salgın) Sürecinde Farklı Branş Sporcularının Belirsizliğe Tahammülsüzlük Düzeylerinin Motivasyonel Kararlılık Tutumlarıyla İlişsi Düzeyinin İncelenmesi
}

\author{
Investigation On The Connection Between Intolerance Against Uncertainty And Motıvational \\ Stabıltty Attıtude Of The Athletes Performing In Different Branches Durıng Covid-19 Pandemic
}

\section{Berat Ergenekon*}

\begin{abstract}
The aim of this study is to investigate the connection between the intolerance against uncertainty and motivational stability attitudes of the athletes performing in different branches during the Pandemic that emerged in Wuhan, China, and identified as the "novel coronavirus" COVID-19. While the team and individual branch athletes who were actively performing in the Eastern and South-eastern Anatolia Regions constitute the universe of the research, the sample group was composed of 504 voluntary team and individual athletes, 253 of whom were females and 251 of whom were males randomly selected from the provinces of Diyarbakır, Gaziantep, Siirt, Batman, Van, Bingöl, Mardin, Şanlurffa, Malatya, Bitlis, Muş, Elazı̆̆ and Sirnak. The following scales were applied to the participants: i) A "demographic information form" developed by the researcher; ii) a five point Likert type "scale of intolerance against uncertainty" developed by Carleton, Norton, \& Asmundson (2007) and adapted to Turkish language by Erguvan et al. consisting of sub-dimensions namely "forward anxiety" and "preventive anxiety"; iii) a five point Likert type "motivational stability scale" developed by Constantin, Holman and Hojbotă (2011) and adapted to Turkish language by Sarıçam et al. (2013), consisting of sub-dimensions namely: "repeating inaccessible targets", "following long-term targets" and "following existing targets". In this process, the athletes' intolerance against uncertainty and their motivational stability attitudes were compared with regard to the demographic information at sub-dimensional level and the relationship between the two scales and the influence of this intolerance on motivational stability attitudes were examined. The number, percentage, average, standard deviation were used as descriptive statistical methods in the evaluation of the data. In the analysis of the data which did not exhibit a normal distribution according to the normality test, the U-test was used to examine whether the difference between the averages of the two groups was significant or not. The SPSS 22.0 package program was used in the analysis of the data and the error margin was accepted as 0.05 . According to the test results, there was no significant difference according to gender and branch variables ( $p>0.05$ ), while significant differences were found according to the education status, psychological education / support status variables $(\mathrm{p}<0.05)$. And significant relationships were found between intolerance against uncertainty and motivational stability attitudes $(* \mathrm{p}<0.01, * * \mathrm{p}<0.05)$.
\end{abstract}

\footnotetext{
*Yüksek Lisans Öğrencisi, Muş Alparslan Üniversitesi, Sosyal Bilimler Enstitüsü, Beden Eğitimi ve Spor Eğitimi ABD MA Student, Muş Alparslan University, Institute of Social Sciences, Department of Physical Education and Sport Education ORCID 0000-0001-5793-9228

beratergenek10@gmail.com

Cite as/ Atıf: Ergenekon, B. (2020). Covid-19 pandemi (salgın) sürecinde farklı branş sporcularının belirsizliğe tahammülsüzlük düzeylerinin motivasyonel kararlılık tutumlarıyla ilişki düzeyinin incelenmesi. Turkish Studies, 15(6), 447-457. https://dx.doi.org/10.7827/TurkishStudies.44358

Received/Geliş: 19 June/Haziran 2020

Accepted/Kabul: 15 October/Ekim 2020

Copyright (C) MDE, Turkey
} 


\section{Structured Abstract: Introduction}

As a result of the exploratory analysis performed on the reported cases, the diagnosis was made on February 11, 2020 (Surveillances, V. 2020). While trying to obtain immunity by delaying the spread of the disease caused by the virus, which does not have any medicine or vaccine yet, experts in many countries around the world have been working intensely in order to develop vaccines and medicines that will eliminate the effect of this virus. The virus that is spread by contact and mouth droplets also struck down the social and cultural activities and made them come to a halt in our country as in the whole world. "Sports" comes first among these activities. It is of great importance that preferences such as mood, belief, nutrition, sleep patterns and lifestyle that affect the immunity are in harmony with the universal general truths (Aslan, 2020). Therefore, these preferences are undeniably important for the athletes. As a matter of fact, the relationship between psychology and sports has reached an even more important level as the awareness increases. The psychological conditions of the athletes have a great influence on their sports and social life. Emotional state is thought to be a predictor of life satisfaction for optimal performance (Ylldiz et.al., 2015). This situation makes it necessary to reveal how this uncertainty process had reflections on the emotional states of the athletes who were used to training constantly, and to what extent these reflections affected their motivational stability attitudes.

Purpose of the Study: To investigate the connection between the intolerance against uncertainty and motivational stability attitudes of the athletes performing in different branches during the Pandemic identified as COVID-19.

Method: While athletes who are performing in different branches in the Eastern and South-eastern Anatolia Regions constitute the universe of the research, the sample group was composed of 504 athletes from different branches, 253 of whom were females and 251 of whom were males selected from 13 provinces located in mentioned regions. A "demographic information form" developed by the researcher was used in the first section. The SPSS 22.0 package program was used in the analysis $(\mathrm{p}<0.05)$. When the normality analysis is examined, it is determined that the data are not normally distributed. In this respect, the U-test was used to examine whether the difference between the averages of two groups was significant and Spearman's correlation test was used to examine the level of relationship between the two variables and simple regression test was used to examine the influence level of the independent variable on the dependent variable.

\section{Data Collection Tools}

Scale of Intolerance against Uncertainty: The five-point Likert type scale developed by Carleton, Norton, \& Asmundson (2007) and adapted to Turkish language by Erguvan et al. (2014) consisting of subdimensions namely: "forward anxiety" (BTÖ 1,2,3,4,5,6,7) and "preventive anxiety" (BTÖ 8,9,10,11,12) was directed to the participants in the form of 12 questions.

Scale of Motivational Stability: The five-point Likert type scale developed by Constantin, Holman and Hojbotă (2011) and adapted to Turkish language by Sarıçam et al. (2013), consisting of sub-dimensions namely: "repeating inaccessible targets" (MKÖ 1,4,7,10,13), "following long-term targets" (MKÖ 2,5,8,11) and "following existing targets" (MKÖ 3,6,9,12) was directed to the participants in the form of 13 questions.

Discussion, Result and Recommendations: No significant difference has been observed according to the gender variable in sub-dimensions: "forward anxiety" (IYK) and "preventive anxiety" (EK) under scale of intolerance against uncertainty as well as in sub-dimensions: "repeating inaccessible targets" (UHY), "following long-term targets" (UVHT) and "following existing targets" (MHT) under motivational stability scale (Table.2). Similarly the study conducted by Karayol et.al.(2019) shows parallelism to our study in terms of gender variability. This situation can be explained by the fact that the global pandemic that is affecting the whole world, has left negative effects on people to a certain extent regardless of their religion, race, language, profession or gender. No significant difference has been observed according to the sports branch variable in sub-dimensions: "forward anxiety" (IYK) and "preventive anxiety" (EK) under scale of intolerance against uncertainty and in sub-dimensions: "repeating inaccessible targets" (UHY), "following long-term targets" (UVHT) and "following existing targets" (MHT) under motivational stability scale (Table.3). A similar study conducted by Civan et al. (2010) shows contrast with our study in terms of sports branch variable. This situation can be explained by the opinion that it is normal to have no significant difference when we consider that the athletes from every branch who are accustomed to being constantly trained may have experienced similar emotional changes due to not leaving the house and being far from 
training and competition environments for a long time due to spreading of the pandemic. While there was no significant difference in sub-dimension: "preventive anxiety (EK)" under scale of intolerance against uncertainty; a significant difference has been observed in sub-dimension: "forward anxiety" (IYK) in favour of the participants at higher education level. When the same table is examined, it is seen that there was no significant difference in the sub-dimensions: "following the long-term targets" (UVHT) and "following existing targets" (MHT) under motivational stability scale, whereas a significant difference was observed in sub-dimension: "repeating inaccessible targets" (UHY) in favour of the participants at higher education level (Table 4). In the sub-dimension "forward anxiety", which is among the sub-dimensions of the scale of intolerance against uncertainty; it can be expressed that athletes at primary and secondary school levels who could not possess enough maturity and experience had more concerns when compared to the athletes of higher education levels who have chosen his/her profession or career path. Likewise, the fact that there was a significant difference in favour of the athletes at higher education level in sub-dimension: "repeating inaccessible targets" under motivational stability scale can be due to the factors that they covered a longer distance in their early lives when compared to the athletes at primary and secondary school levels and they might have lived more positive and negative experiences and these experiences might have attracted them to these targets. While there was no significant difference in the sub-dimension: "repeating inaccessible targets" (UHY) under motivational stability scale according to the psychological education / support variable, a significant difference has been observed in favour of "yes" option in the sub-dimensions: "forward anxiety" (IYK) and "preventive anxiety" (EK) under scale of intolerance against uncertainty and sub-dimensions: "following long term targets" (UVHT) and "following existing targets" (MHT) under motivational stability scale (Table 5). Similarly, the study conducted by Küçük and Koç (2004) is parallel with our study regarding the psychological education / support variable. It is seen that the athletes who did not receive any training / support on sports psychology were insufficient in emotional management under unexpected conditions and were weaker in keeping their motivational attitudes at high levels, therefore it can be concluded that mental and psychiatric support had a significant effect on athletes. A low-level positive correlation was found between the sub-dimensions: "forward anxiety"; and "repeating inaccessible targets", "following long-term targets" and "following existing targets". While there was a low-level positive correlation between the subdimensions: "preventive anxiety" and "repeating inaccessible targets", no significant relationship was found between the sub-dimensions: "following long-term targets" and "following existing targets" (Table6). Similarly, the study put forward by Küçükkömürler (2017) is parallel with our study with regard to the fact that intolerance against uncertainty is related to the motivational stability attitudes. In this case, considering the uncertainty situations of the athletes and the limits of their tolerance against uncertainty will be an important factor that will help us in motivational studies to be performed on athletes. Especially in this challenging period that we are going through, the forward anxiety situations of the athletes are seen as an important factor in maintaining their goals. Preventive anxiety affects the athletes about the targets they cannot achieve and thus making it important to perform the psychological and mental studies not only at the professional level but also at groundwork and amateur levels. The intolerance against uncertainty significantly affects motivational stability attitudes by $06 \%$ (Table.7). In this respect, the steps to be taken in reducing the uncertainty will increase motivational attitudes and stability scores. This study reveals the impact of emotion management on athletes in the face of this global pandemic that we have experienced or any unexpected situations that we may experience in the future and that important steps should be taken in this field in order to be more prepared in potential situations.

Keywords: Physical Education and Sports, Covid-19, Uncertainty, Motivation

Öz: Bu araştırmanın amacı, Çin'in Wuhan kentinde ortaya çıkan ve "yeni koronavirüs" COVID-19 olarak teşhis edilen Pandemi (Salgın) sürecinde farklı branş sporcularının belirsizliğe tahammülsüzlük düzeylerinin motivasyonel kararlılık tutumlarıyla ilişki ve etki düzeyinin incelenmesidir. Araştırmanın evrenini Doğu ve Güneydoğu Anadolu Bölgesi'nde aktif durumda olan takım ve ferdi branş sporcuları oluştururken, örneklem grubunu ise bu bölgelerde yer alan Diyarbakır, Gaziantep, Siirt, Batman, Van, Bingöl, Mardin, Şanlıurfa, Malatya, Bitlis, Muş, Elazığ ve Şırnak şehirlerinden rastgele seçilmiş 253'ü kadın, 251'i erkek toplam 504 farklı branşlardan gönüllü olarak takım sporcuları ve ferdi sporcular oluşturmaktadır. Katılımcılara araştırmacı tarafindan oluşturulan 'demografik bilgi formu', Carleton, Norton, \& Asmundson (2007) tarafından geliştirilen, Erguvan ve ark. tarafindan Türkçe'ye uyarlanan ileriye yönelik kaygı ve engelleyici kaygı alt boyutlarından oluşan beşli likert tipi olan 'belirsizliğe tahammülsüzlük ölçeği' ve Constantin, Holman ve Hojbotă (2011) tarafından geliştirilen, Sarıçam ve ark. (2013) tarafından Türkçeye uyarlanan 
ulaşılamayan hedefleri yineleme, uzun vadeli hedefleri takip ve mevcut hedefleri takip alt boyutlarından oluşan beşli likert tipi olan 'motivasyonel kararlılık ölçeği' yöneltilmiştir. Bu süreçte sporcuların belirsizliğe tahammülsüzlük düzeyleri ve motivasyonel kararlılık tutumları alt boyutlar düzeyinde demografik bilgiler ile karşılaştırılmış ve iki ölçek arasındaki ilişki düzeyine sonra da belirsizliğe tahammülsüzlüğün motivasyonel kararlılık tutumlarına etkisi incelenmiştir. Çalışmamız için sunduğumuz etik kurul raporu, Muş Alparslan Üniversitesi Rektörlüğü Bilimsel Araştırma ve Yayın Etiği Kurulu’nun 12.10.2020 tarihli, 9 sayılı toplantısında alınan 23 numaralı karar ile etik olarak uygun görülmüş ve kurul tarafindan onaylanmıştır. Verilerin değerlendirilmesinde tanımlayıcı istatistiksel yöntemleri olarak sayı, yüzde, ortalama, standart sapma uygulanmıştır. Yapılan normallik testine göre normal dağılım göstermeyen verilerin analizinde, iki değişken ortalamaları arasındaki farkın anlamlı olup olmadığını incelemek için U-testi kullanılmıştır. Verilerin analizinde SPSS 22.0 paket programı kullanılmış olup hata payı 0.05 olarak kabul edilmiştir. Yapılan test sonuçlarına göre cinsiyet ve branş değişkenlerine göre anlamlı bir farklılık görülmezken ( $>0,05)$, eğitim durumu, psikolojik eğitim/destek durumu değişkenlerine göre anlamlı farklılıklar tespit edilmiştir $(\mathrm{p}<0,05)$. Ve belirsizliğe tahammülsüzlük ile motivasyonel kararlılık tutumları arasında anlamlı ilişkiler olduğu saptanmıştır $(* \mathrm{p}<0,01, * * \mathrm{p}<0,05)$.

Anahtar Kelimeler: Beden Eğitimi ve Spor, Covid-19, Belirsizlik, Motivasyon

\section{Giriş}

Coronavirüs geniş bir virüs ailesinin adı olup şuan karşı karşıya kaldığımız son üyesi olan COVID-19, öngörülmesi zor bir şekilde hızla yayılan bir virüstür (Yılmaz, 2020). Rapor edilen tüm vakalardaki tanımlayıcı verilere yapılan keşifsel analiz sonucunda 11 Şubat 2020 itibariyle teşhisleri konmuş oldu (Surveillances, 2020). Bu ailenin diğer üyeleri olarak bilinen SARS ve MERS virüslerinden çok daha etkili olduğu bilinmektedir. Dünyanın hemen her yerinde oldukça yaygın bir salgın oluşturan COVID-19, hayatı oldukça ciddi düzeylerde tehdit altında tutmaya devam etmekte. Beklenmedik bir anda, 2019 Aralık ayı içinde Çin'in Wuhan kenti Hubei eyaletinde baş gösteren bu salgın hakkında elde olan bilgiler her geçen gün değişim gösterirken, virüsün hızlı bulaşma özelliği, enfekte ve ölüm oranlarının sürekli artış göstermesi nedeniyle varlık gösteren panik ve endişe bir tür korku haline dönüşüm göstermiştir (Üstün, 2020). Henüz ilacı veya aşısı bulunmayan bu virüs için hastalığın yayılmasını geciktirerek zaman ve bağışıklık kazanmaya çalış1lırken dünyanın birçok ülkesinde uzmanlar bu virüsün etkisini yok edecek aşı ve ilaç geliştirmek için yoğun bir çalışma içindeler. Ülkelerin hastanelerinde enfekte hastalar için yeterli yatak kapasitesi, sağl1k malzemeleri ve sağlık personellerinin bulunması, yağmalama olaylarının ya da gıda stokçuluğunun ciddi anlamda yapılmaması küresel ve ulusal çaptaki kriz döneminde bir ülkede sürecin başarılı bir şekilde yürütüldügünün göstergesi olabilir. Bu bağlamda ülkemiz Bakanlıklarının kriz yönetiminde olumlu bir sınav verdiklerini söylemek yanlış bir ifade olmayacaktır (Erdem, 2020). Sağlık alanında pek çok uzman kişi ve kuruluşlar akla gelebilecek her tedbiri ve insanların kendini izole edebilmesi amaciyla gereken tavsiyeleri vermektedir. $\mathrm{Bu}$ tavsiyelerden belki de en önemlisi virüsün yayılmasının önüne geçebilmek adına yapılan "evde kal" çağrılarıdır. Tam da bu sebeple toplumsal hayata dair bu gelişmeler ve değişmelerin yalnızca sağlık alanı nezdinde değerlendirilmesi yeterli olmamaktadır. Çünkü söz konusu olan pandemi aktif ve sosyal bir varlık olan insanı "sosyal mesafe" bağlamında zorlayıcı ve sınırlayıcı bir sonuç ortaya çıkarmaktadır (Tekin, 2020). Temas ve ağızdan çıkan damlacıklarla yayılan bu virüs sosyal ve kültürel faaliyetlere de ağır bir darbe vurmuş ve tüm dünyada olduğu gibi ülkemizde de bu faaliyetler durma noktasına ulaşmıştır. Bu faaliyetlerin başında da şüphesiz ki "spor" gelmektedir.

Bağışıklığı etkileyen duygu durumu, inanç, beslenme, uyku düzeni ve hayat tarzı gibi tercihlerin evrensel genel doğrularla uyum içinde olması oldukça önem arz etmektedir (Aslan, 2020). Bütün bu etkenler bir sporcu için işleyen bir mekaniğin sistematik birer parçaları gibi ayrılmaz bir bütün olarak düşünülebilir. Bu yüzden bu tercihler bir sporcu için yadsınamaz derecede önemlidir. Nitekim psikoloji ile spor arasındaki ilişki farkındalık arttıkça daha da önemli bir ölçüye ulaşmıştır. Sporcuların içinde bulundukları psikolojik durumların da spor ve sosyal 
yaşantılarına etkisi büyüktür. Optimal performans için duygu durumunun yaşam tatmininin bir yordayıcısı olduğu düşünülmektedir. (Yıldız vd., 2015). Özellikle ülkemizde ilk defa bu denli etkili olan bir virüsün yayılması sporcular üzerinde de bir endişeye yol açabileceğinden, bu endişenin tahammül sınırlarına belli düzeylerde etki edebileceği düşüncesine yol açabilir. Bu da yaşanan bu zorlu sürecin, sürekli antrenman haline alışık sporcuların duygu durumlarına ne gibi yansımaları olduğunu ve bu yansımaların motivasyonel kararlılık tutumlarını ne düzeyde etkilediğini ortaya koymayı gerekli kılmaktadır. Psikolojide istekler ve ihtiyaçların motivasyon başlı̆̆ı altında incelendiği ifade edilmektedir (Arkonaç, 1998). Ayrıca motivasyonun sporcuyu başarıya götüren köprünün temellerinden önemli bir parça olduğu bilinmektedir. Sporcular için motivasyonel kararlılık düzeyinin başarıya giden yoldaki azim ve istek düzeyi ile doğru orantılı olduğu söylenebilir. Bütün bunlar bir araya geldiğinde bu çalışma, tüm dünyada olduğu gibi ülkemizin de içinde bulunduğu bu zorlu ve yıpratıcı sürecin, sporcularda belirsizliğin getirdiği tahammülsüzlük seviyesini ve sporcular için bu denli etkili olan motivasyonel kararlılık düzeyi ilişkisini ve etkilerini ortaya koymayı hedeflemektedir.

\section{Yöntem}

Araştırmanın evrenini Doğu ve Güneydoğu Anadolu Bölgeleri’nde aktif durumda olan farklı branşlarda takım ve ferdi sporcular oluştururken, örneklem grubunu ise bu bölgelerde yer alan Diyarbakır, Gaziantep, Siirt, Batman, Van, Bingöl, Mardin, Şanlıurfa, Malatya, Bitlis, Muş, Elazı ̆ ve Şırnak şehirlerinden rastgele seçilmiş 253'ü kadın, 251'i erkek toplam 504 farklı branşlardan gönüllü olarak takım sporcuları ve ferdi sporcular oluşturmaktadır. Çalışmanın birinci bölümünde araştırmacı tarafindan oluşturulmuş 'demografik bilgi formu' kullanılmıştır. $\mathrm{Bu}$ demografik bilgiler cinsiyet, eğitim durumu, şehir, spor branşı, psikolojik eğitim/destek durumu gibi değişkenlerden oluşmaktadır. Çalışmanın ikinci bölümünde ise Carleton, Norton, \& Asmundson (2007) tarafından geliştirilen, Erguvan ve ark. (2014) tarafından türkçeye uyarlanan ileriye yönelik kayg1 (BTÖ 1,2,3,4,5,6,7) ve engelleyici kayg1 (BTÖ 8,9,10,11,12) alt boyutlarından oluşan beşli likert tipi olan 'belirsizliğe tahammülsüzlük ölçeği ve Constantin, Holman ve Hojbotă (2011) tarafından geliştirilen, Sarıçam ve ark. (2013) tarafından Türkçe’ye uyarlanan ulaşllamayan hedefleri yineleme (MKÖ 1,4,7,10,13), uzun vadeli hedefleri takip (MKÖ 2,5,8,11) ve mevcut hedefleri takip (MKÖ 3,6,9,12) alt boyutlarından oluşan beşli likert tipi olan 'motivasyonel kararlılık ölçeği' toplamda 25 soru olarak katılımcılara yöneltilmiştir. Verilerin analizinde SPSS 22.0 paket programı kullanılmış olup hata payı 0.05 olarak kabul edilmiştir. Verilerin değerlendirilmesinde tanımlayıcı istatistiksel yöntemleri olarak sayı, yüzde, ortalama, standart sapma uygulanmıştır. Yapılan normallik analizine bakılarak kolmogorov-smirnov, skewness-kurtosis, histogram ve normal Q-Q plot değerlerine dikkat edildiğinde verilerin normal dağılmadığı saptanmıştır. Bu bağlamda iki grubun ortalamaları arasındaki farkın anlamlı olup olmadığını incelemek için U-testi, iki değişken arasındaki ilişki düzeyini incelemek için spearman's korelasyon testi, bağımsız değişkenin bağımlı değişken üzerindeki etki düzeyini incelemek için basit regresyon testi kullanılmıştır. Çalışmamız için sunduğumuz etik kurul raporu, Muş Alparslan Üniversitesi Rektörlüğü Bilimsel Araştırma ve Yayın Etiği Kurulu'nun 12.10.2020 tarihli, 9 sayılı toplantısında alınan 23 numaralı karar ile etik olarak uygun görülmüş ve kurul tarafından onaylanmıştır.

\section{Bulgular}

Araştırmada elde edilen verilerin analizleri neticesinde, tablolar ve yorumlamalarına bu bölümde yer verilmiştir. 
Tablo 1: Araştırma Örnekleminin Demografik Özellikleri

Değişken Frekans(f) $\quad$ Yüzde (\%)

\begin{tabular}{lll}
\cline { 2 - 3 } Cinsiyet & & \\
\hline Kadın & 253 & 50,2 \\
Erkek & 251 & 49,8 \\
Toplam: & 504 & 100,0 \\
\hline Ĕgitim Düzeyi & \\
\hline İk ve Ortaöğretim & 206 & 40,9 \\
Yükseköğretim & 298 & 59,1 \\
Toplam: & 504 & 100,0 \\
\hline Psikolojik Eğitim/Destek & & \\
\hline Evet & 151 & 30,0 \\
Hayır & 353 & 70,0 \\
Toplam: & 504 & 100,0 \\
\hline Spor Branș Dağlımı & & \\
Takımsporları & 333 & 66,1 \\
Ferdibranşlar & 171 & 33,9 \\
Toplam: & 504 & 100,0 \\
\hline
\end{tabular}

Tablo 1: Katılımcılar cinsiyet değişkenine göre 253'ü kadın (\%50,2), 251'i erkek (\%49,9), olarak dağılmaktadır. Katılımcılar eğitim düzeyi değişkenine göre 206 's1 ilk ve orta öğretim $(\% 40,9)$, 251'i yükseköğretim $(\% 59,1)$ olarak dağılım göstermektedir. Katılımcılar Psikolojik eğitim/destek değişkenine göre 151'i evet $(\% 30,0), 353$ 'ü ise hayır $(\% 70)$ olarak dağılım göstermektedir. Katılımcılar spor branşı değişkenine göre ise 333’ü takım sporları $(\% 66,1), 171$ ’i ferdi sporlar $(\% 33,9)$ olarak dağılım göstermektedir.

Tablo 2: Temel Değişkenlerin Alt Boyutlar Düzeyinde Cinsiyet Değişkenine Göre U-Testi Sonuçları

\begin{tabular}{|c|c|c|c|c|c|c|}
\hline & Cinsiyet & $\mathbf{N}$ & Sira Ort. & Sira Top. & $\mathbf{U}$ & $\mathbf{P}$ \\
\hline \multirow{3}{*}{ İYK } & Kadın & 253 & 261,18 & 66079,00 & & \\
\hline & Erkek & 251 & 243,75 & 61181,00 & 29555,00 &, 17 \\
\hline & Toplam & 504 & & & & \\
\hline \multirow{3}{*}{ EK } & Kadın & 253 & 264,59 & 66941,50 & & \\
\hline & Erkek & 251 & 240,31 & 60318,50 & 28692,50 &, 06 \\
\hline & Toplam & 504 & & & & \\
\hline \multirow{3}{*}{ UHY } & Kadın & 253 & 257,36 & 65113,00 & & \\
\hline & Erkek & 251 & 247,60 & 62147,00 & 30521,00 &, 45 \\
\hline & Toplam & 504 & & & & \\
\hline \multirow{3}{*}{ UVHT } & Kadın & 253 & 245,95 & 62225,00 & & \\
\hline & Erkek & 251 & 259,10 & 65035,00 & 30094,00 &, 30 \\
\hline & Toplam & 504 & & & & \\
\hline \multirow{3}{*}{ MHT } & Kadın & 253 & 245,20 & 62034,50 & & \\
\hline & Erkek & 251 & 259,86 & 65225,50 & 29903,50 &, 25 \\
\hline & Toplam & 360 & & & & \\
\hline
\end{tabular}

Tablo 2: İncelendiğinde, belirsizliğe tahammülsüzlük ölçeği alt boyutlarından ileriye yönelik kaygı (IYK), engelleyici kaygı (EK) ve motivasyonel kararlılık ölçeği alt boyutlarından 
ulaşılamayan hedefleri yineleme (UHY), uzun vadeli hedefleri takip (UVHT), mevcut hedefleri takip (MHT) alt boyutlarında cinsiyet değişkenine göre anlamlı bir farklılık görülmemektedir $(\mathrm{p}>0,05)$.

Tablo 3: Temel Değişkenlerin Alt Boyutlar Düzeyinde Branş Değişkenine Göre U-Testi Sonuçları

\begin{tabular}{|c|c|c|c|c|c|c|}
\hline & Branş & $\mathbf{N}$ & Sira Ort. & Sira Top. & $\mathbf{U}$ & $\bar{P}$ \\
\hline \multirow{3}{*}{ İYK } & $\begin{array}{l}\text { Takım } \\
\text { Sporlanı }\end{array}$ & 333 & 259,26 & 86335,00 & & \\
\hline & $\begin{array}{l}\text { Ferdi } \\
\text { Sporlar }\end{array}$ & 171 & 239,33 & 40925,00 & 26219,00 &, 14 \\
\hline & Toplam & 504 & & & & \\
\hline \multirow{3}{*}{ EK } & $\begin{array}{l}\text { Takım } \\
\text { Sporları }\end{array}$ & 333 & 251,67 & 83804,50 & & \\
\hline & $\begin{array}{l}\text { Ferdi } \\
\text { Sporlar }\end{array}$ & 171 & 254,13 & 43455,50 & 28193,50 & ,85 \\
\hline & Toplam & 504 & & & & \\
\hline \multirow{3}{*}{ UHY } & $\begin{array}{l}\text { Takım } \\
\text { Sporları }\end{array}$ & 333 & 254,11 & 86619,50 & & \\
\hline & $\begin{array}{l}\text { Ferdi } \\
\text { Sporlar }\end{array}$ & 171 & 249,36 & 42640,50 & 27934,50 &, 72 \\
\hline & Toplam & 504 & & & & \\
\hline \multirow{3}{*}{ UVHT } & $\begin{array}{l}\text { Takım } \\
\text { Sporlanı }\end{array}$ & 333 & 250,89 & 83547,50 & & \\
\hline & $\begin{array}{l}\text { Ferdi } \\
\text { Sporlar }\end{array}$ & 171 & 255,63 & 43712,50 & 27936,50 &, 72 \\
\hline & Toplam & 504 & & & & \\
\hline \multirow{3}{*}{ MHT } & $\begin{array}{l}\text { Takım } \\
\text { Sporları }\end{array}$ & 333 & 254,61 & 84785,50 & & \\
\hline & $\begin{array}{l}\text { Ferdi } \\
\text { Sporlar }\end{array}$ & 171 & 248,39 & 42474,50 & 27768,50 & ,64 \\
\hline & Toplam & 360 & & & & \\
\hline
\end{tabular}

Tablo 3: İncelendiğinde, belirsizliğe tahammülsüzlük ölçeği alt boyutlarından ileriye yönelik kaygı (IYK), engelleyici kaygı (EK) ve motivasyonel kararlılık ölçeği alt boyutlarından ulaşılamayan hedefleri yineleme (UHY), uzun vadeli hedefleri takip (UVHT), mevcut hedefleri takip (MHT) alt boyutlarında spor branşları değişkenine göre anlamlı bir farklılık görülmemektedir $(\mathrm{p}>0,05)$. 
Tablo 4: Temel Değişkenlerin Alt Boyutlar Düzeyinde Eğitim Durumu Değiş̧kenine Göre U-Testi Sonuçları

\begin{tabular}{|c|c|c|c|c|c|}
\hline & $\begin{array}{ll}\text { Eğitim } \\
\text { Durumu }\end{array}$ & Sira Ort. & Sira Top. & $\mathbf{U}$ & $\mathbf{P}$ \\
\hline \multirow{3}{*}{ IYYK } & $\begin{array}{ll}\text { İlk } & \text { ve } \\
\text { Ortaöğretim } & \end{array}$ & 268,12 & 55232,00 & & \\
\hline & Yükseköğretim 298 & 241,70 & 72028,00 & 27477,00 &, 04 \\
\hline & $\begin{array}{ll}\text { Toplam } & 504\end{array}$ & & & & \\
\hline \multirow{3}{*}{ EK } & $\begin{array}{ll}\text { İlk } & \text { ve } \\
\text { Ortaöğretim } & \\
\end{array}$ & 262,08 & 53987,50 & & \\
\hline & Yükseköğretim 298 & 245,88 & 73272,50 & 28721,50 & ,21 \\
\hline & $\begin{array}{ll}\text { Toplam } & 504 \\
\end{array}$ & & & & \\
\hline \multirow{3}{*}{ UHY } & $\begin{array}{ll}\text { İlk } & \text { ve } \\
\text { Ortaöğretim } & \\
\end{array}$ & 269,18 & 55450,50 & & \\
\hline & Yükseköğretim 298 & 240,97 & 71809,50 & 27258,50 & ,03 \\
\hline & Toplam $\quad 504$ & & & & \\
\hline \multirow{3}{*}{ UVHT } & $\begin{array}{ll}\text { İlk } & \text { ve } \\
\text { Ortaöğretim } & \end{array}$ & 259,97 & 53554,00 & & \\
\hline & Yükseköğretim 298 & 247,34 & 73706,00 & 29155,00 & ,33 \\
\hline & $\begin{array}{ll}\text { Toplam } & 504 \\
\end{array}$ & & & & \\
\hline \multirow{3}{*}{ MHT } & $\begin{array}{ll}\text { İlk } & \text { ve } \\
\text { Ortaöğretim } & \end{array}$ & 257,31 & 53006,50 & & \\
\hline & Yükseköğretim 298 & 249,17 & 74253,50 & 29702,50 &, 53 \\
\hline & $\begin{array}{ll}\text { Toplam } & 360 \\
\end{array}$ & & & & \\
\hline
\end{tabular}

Tablo 4: İncelendiğinde, belirsizliğe tahammülsüzlük ölçeği alt boyutlarından engelleyici kaygı (EK) alt boyutunda eğitim düzeyi değişkenine göre anlamlı bir farklılık görülmezken ( $p>0,05)$, ileriye yönelik kaygı (IYK) alt boyutunda yükseköğretim düzeyinde olan katılımcılar lehine anlamlı bir farklılık görülmektedir $(p<0,05)$. Yine aynı tablo incelendiğinde motivasyonel kararlılık tutumları ölçeği alt boyutlarından uzun vadeli hedefleri takip (UVHT) ve mevcut hedefleri takip (MHT) alt boyutlarında anlamlı bir farklılığa rastlanmazken ( $>>0,05)$, ulaşılamayan hedefleri yineleme (UHY) alt boyutunda yükseköğretim düzeyinde olan katılımcılar lehine anlamlı bir farklılık görülmektedir $(\mathrm{p}<0,05)$.

Tablo 5: Temel Değişkenlerin Alt Boyutlar Düzeyinde Psikolojik Eğitim/Destek Değişkenine Göre U-Testi Sonuçları

\begin{tabular}{|c|c|c|c|c|c|c|}
\hline & $\begin{array}{l}\text { Psikolojik } \\
\text { Eğitim/Destek }\end{array}$ & $\mathbf{N}$ & Sira Ort. & Sira Top. & $\mathbf{U}$ & $\mathbf{P}$ \\
\hline \multirow{3}{*}{ İYK } & Evet & 151 & 224,47 & 33894,50 & & \\
\hline & Hayır & 353 & 264,49 & 93365,50 & 22418,50 & 00 \\
\hline & Toplam & 504 & & & & \\
\hline \multirow{3}{*}{ EK } & Evet & 151 & 223,44 & 33739,00 & & \\
\hline & Hayır & 353 & 264,93 & 95521,00 & 22263,00 & 00 \\
\hline & Toplam & 504 & & & & \\
\hline \multirow{3}{*}{ UHY } & Evet & 151 & 239,34 & 36140,00 & & \\
\hline & Hayır & 353 & 258,13 & 91120,00 & 24664,00 &, 18 \\
\hline & Toplam & 504 & & & & \\
\hline \multirow{3}{*}{ UVHT } & Evet & 151 & 291,60 & 44031,50 & & \\
\hline & Hayır & 335 & 235,77 & 83228,50 & 20747,50 &, 00 \\
\hline & Toplam & 504 & & & & \\
\hline \multirow{3}{*}{ MHT } & Evet & 151 & 274,21 & 41406,00 & & \\
\hline & Hayır & 353 & 243,21 & 85854,00 & 23373,00 &, 02 \\
\hline & Toplam & 360 & & & & \\
\hline
\end{tabular}


Tablo 5: İncelendiğinde, motivasyonel kararlılık ölçeği alt boyutlarından ulaşılamayan hedefleri yineleme (UHY) alt boyutunda anlamlı bir farklılık görülmezken ( $>0,05)$, belirsizliğe tahammülsüzlük ölçeği alt boyutlarından ileriye yönelik kaygı (IYK), engelleyici kaygı (EK) ve motivasyonel kararlılık ölçeği alt boyutlarından, uzun vadeli hedefleri takip (UVHT) ve mevcut hedefleri takip (MHT) alt boyutlarında psikolojik eğitim/destek değişkenine göre 'evet' lehine anlamlı bir farkl11ık görülmektedir $(\mathrm{p}<0,05)$.

Tablo 6: Belirsizliğe Tahammülsüzlük İle Motivasyonel Kararlılık Tutumlarının Alt Faktörler Düzeyinde İncelenmesi

\begin{tabular}{|c|c|c|c|c|c|}
\hline Faktör & 1 & 2 & 3 & 4 & 5 \\
\hline 1. İleriye Yönelik Kaygı & - & & & & \\
\hline 2. Engelleyici Kayg1 &, $608 * *$ & - & & & \\
\hline 3.Ulaşılamayan Hedefleri Yineleme &, $362 * *$ &, $307 * *$ & - & & \\
\hline $\begin{array}{l}\text { 4. Uzun Vadeli Hedefleri } \\
\text { Takip }\end{array}$ &, $107 *$ &, 020 &, $415^{* *}$ & - & \\
\hline 5.Mevcut Hedefleri Takip &, $103 *$ &,- 074 &, $377 * *$ &, $690 * *$ & - \\
\hline
\end{tabular}

Tablo 6: İncelendiğinde ileriye yönelik kaygı ile ulaşılamayan hedefleri yineleme $(r=.362$, $\mathrm{p}<0,01)$, uzun vadeli hedefleri takip $(r=.107, \mathrm{p}<0,05)$, mevcut hedefleri takip $(r=.103, p<0,05)$ alt boyutları arasında düşük seviyede pozitif yönde anlamlı bir ilişki bulunmuştur. Engelleyici kaygı ile ulaşılamayan hedefleri yineleme $(\mathrm{r}=.307, \mathrm{p}<0,01)$ alt boyutu arasında düşük seviyede pozitif yönde anlamlı bir ilişki bulunurken, uzun vadeli hedefleri takip ve mevcut hedefleri takip alt boyutlarında anlamlı bir ilişki bulunmamıştır.

Tablo 7: Belirsizliğe Tahammülsüzlük Düzeyinin Motivasyonel Kararlılık Tutumlarına Etkisi Yordayan Regresyon Tablosu

\begin{tabular}{lccccc}
\hline Model & $\boldsymbol{\beta}$ & $\mathbf{R}$ & $\mathbf{R}^{\mathbf{2}}$ & F Değeri & $\begin{array}{l}\text { ANOVA } \\
\text { P değeri }\end{array}$ \\
\hline $\begin{array}{l}\text { Model 1 } \\
\begin{array}{l}\text { Belirsizliğe } \\
\text { Tahammülsüzlük }\end{array}\end{array}$ &, 208 &, 254 &, 064 & 34,574 &, 001 \\
\hline
\end{tabular}

Durbin Watson= 1,778; Bağımlı Değişken: Motivasyonel Kararlılık Tutumları; $p<0.05$

Tablo.7 İncelendiğinde belirsizliğe tahammülsüzlük değişkeni, motivasyonel kararlılık tutumları değişkenini $\% 06$ oranında anlamlı bir şekilde etkilemektedir $(F=34.574, \beta=.208$, $\mathrm{p}<0.05)$.

\section{Tartışma, Sonuç ve Öneriler}

Belirsizliğe tahammülsüzlük ölçeği alt boyutlarından ileriye yönelik kaygı (IYK), engelleyici kaygı (EK) ve motivasyonel kararlılık ölçeği alt boyutlarından ulaşılamayan hedefleri yineleme (UHY), uzu vadeli hedefleri takip (UVHT), mevcut hedefleri takip (MHT) alt boyutlarında cinsiyet değişkenine göre anlamlı bir farklılık görülmemektedir (Tablo.2). Benzer 
şekilde Karayol ve diğerleri (2019) tarafından yapılan çalışma da yapmış olduğumuz çalışmaya cinsiyet değişkenliği açısından paralellik göstermektedir. Bu durum yaşamış olduğumuz bu süreçte dünyayı etkisi altına alan küresel salgının her türlü din, ırk, dil, meslek yada cinsiyete bakmaksızın insanlara belli ölçülerde olumsuz etkiler bırakması ile açıklanabilir. Belirsizliğge tahammülsüzlük ölçeği alt boyutlarından ileriye yönelik kaygı (IYK), engelleyici kaygı (EK) ve motivasyonel kararlılık ölçeği alt boyutlarından ulaşılamayan hedefleri yineleme (UHY), uzun vadeli hedefleri takip (UVHT), mevcut hedefleri takip (MHT) alt boyutlarında spor branşları değişkenine göre anlamlı bir farklılık görülmemektedir (Tablo.3). Civan ve diğerleri (2010) tarafindan yapılan benzer bir çalışma spor branşları değişkenliği açısından çalışmamıza zıtlık göstermektedir. $\mathrm{Bu}$ durum sürekli antrene halde bulunmaya alışkın her branştan sporcuların salgının yayılmasıyla evden çıkamama, antrenman ve müsabaka ortamından uzun bir süre ayrı kalma durumunda benzer duygusal değişimler yaşamış olabilecekleri düşünüldüğünde anlamlı farkl1lık görülmemesinin normal karşılanabileceği görüşüyle açıklanabilir. Belirsizliğe tahammülsüzlük ölçeği alt boyutlarından engelleyici kaygı (EK) alt boyutunda eğitim düzeyi değişkenine göre anlamlı bir farkl1lık görülmezken, ileriye yönelik kaygı (IYK) alt boyutunda yükseköğretim düzeyinde olan katılımcılar lehine anlamlı bir farklılık görülmektedir. Yine aynı tablo incelendiğinde motivasyonel kararlılık tutumları ölçeği alt boyutlarından uzun vadeli hedefleri takip (UVHT) ve mevcut hedefleri takip (MHT) alt boyutlarında anlamlı bir farklılığa rastlanmazken, ulaşılamayan hedefleri yineleme (UHY) alt boyutunda yükseköğretim düzeyinde olan katılımcılar lehine anlamlı bir farklılık görülmektedir (Tablo.4). Belirsizliğe tahammülsüzlük ölçeği alt boyutlarından ileriye yönelik kaygı değişkeninde meslek veya kariyer yolunu belirlemiş veya bu doğrultuya henüz gençlik çağlarında yeterli olgunluğa ve tecrübeye ulaşmamış olan ilk ve ortaöğretim düzeyindeki sporculara göre daha yakın konumda olan yükseköğretim seviyesindeki sporcular açısından daha fazla kaygı taşıdıkları şeklinde açıklamak mümkündür. Yine motivasyonel kararlılık ölçeği alt boyutlarından ulaşılamayan hedefleri yineleme değişkeninde yükseköğretim düzeyindeki sporcular lehine anlamlı farklılık olması geriye dönük yaşantılarında ilk ve ortaöğretim düzeyindeki sporculara göre daha büyük ölçüde yol katetmeleri, olumlu-olumsuz daha fazla tecrübeler yaşamış olabilecekleri ve bu tecrübelerin onları yine bu hedeflere çekebilmesi şeklinde açıklanabilir. Motivasyonel kararlılık ölçeği alt boyutlarından ulaşılamayan hedefleri yineleme (UHY) alt boyutunda psikolojik eğitim/destek değişkenine göre anlamlı bir farklılık görülmezken, belirsizliğe tahammülsüzlük ölçeği alt boyutlarından ileriye yönelik kaygı (IYK), engelleyici kaygı (EK) ve motivasyonel kararlılık ölçeği alt boyutlarından, uzun vadeli hedefleri takip (UVHT) ve mevcut hedefleri takip (MHT) alt boyutlarında psikolojik eğitim/destek değişkenine göre 'evet' lehine anlamlı bir farklılık görülmektedir (Tablo.5). Benzer şekilde Küçük ve Koç (2004) tarafından yapılan çalışma da yapmış olduğumuz çalışmaya pikolojik eğitim/destek değişkenine göre paralellik göstermektedir. Spor psikolojisi konusunda herhangi bir eğitim/destek almayan sporcuların beklenmedik koşullarda duygu yönetimi konusunda eksik kaldığı ve motivasyonel tutumlarını üst seviyelerde tutabilme konusunda daha zayıf kaldığı görülmekte olup, mental ve psikiyatrik desteğin sporcular üzerinde önemli ölçüde bir etkisi olduğu kanaatine varılabilmektedir. İleriye yönelik kaygı ile ulaşılamayan hedefleri yineleme, uzun vadeli hedefleri takip, mevcut hedefleri takip alt boyutları arasında düşük seviyede pozitif yönde anlamlı bir ilişki bulunmuştur. Engelleyici kaygı ile ulaşılamayan hedefleri yineleme alt boyutu arasında düşük seviyede pozitif yönde anlamlı bir ilişki bulunurken, uzun vadeli hedefleri takip ve mevcut hedefleri takip alt boyutlarında anlamlı bir ilişki bulunmamıştır (Tablo.6). Benzer bir şekilde Küçükkömürler (2017) tarafından ortaya konan çalışma da yapmış olduğumuz çalışmaya belirsizliğe tahammülsüzlük durumlarının motivasyonel kararlılık tutumlarıyla ilişkili olduğu yönünde paralellik göstermektedir. $\mathrm{Bu}$ durumda sporcularda yapılacak motivasyonel çalışmalarda sporcuların belirsizlik durumları ve belirsizliğe tahammül sınırlarını göz önünde bulundurmak bize yardımcı olacak önemli bir husus olarak öne çıkacaktır. Sporcuların özellikle yaşamış olduğumuz bu zorlu süreçte ileriye yönelik kaygı durumları hedeflerini muhafaza etmeleri konusunda önemli bir etken olarak görülmektedir. Engelleyici kaygı durumu ise sporculara ulaşamadıkları hedefler hususunda 
etki etmekte, bu durumda psikolojik ve mental çalışmaların sadece profesyonel düzeyde değil alt yap1 ve amatör düzeylere indirgenmesini önemli kılmaktadır. Belirsizliğe tahammülsüzlük değişkeni, motivasyonel kararlılık tutumları değişkenini \%06 oranında anlamlı bir şekilde etkilemektedir (Tablo.7). Bu durumda belirsizliğin azaltılması konusunda atılacak adımlar motivasyonel tutumlar ve kararlılık puanlarını arttıracaktır. Bu çalışma da yaşamış olduğumuz bu küresel salgın veya yaşayabileceğimiz herhangi beklenmedik durumlar karşısında duygu yönetiminin sporcular üzerindeki etkisini ve yaşanılabilecek durumlarda daha hazırlıklı olunabilmesi adına bu alanda önemli adımlar atılması gerektiğini ortaya koymaktadır.

\section{Kaynakça}

Arkonaç, S. A. (1998). Sosyal psikoloji. Alfa Basım Yayım Dağıtım.

Aslan, R. (2020) Tarihten Günümüze Epidemiler, Pandemiler ve Covid-19. Ayrıntı Dergisi, 8(65): $35-41$.

Civan, A., Arı, R., Görücü, A., \& Özdemir, M. (2010). Bireysel ve takım sporcularının müsabaka öncesi ve sonrası durumluk ve sürekli kaygı düzeylerinin karşılaştırılması. Uluslararası Insan Bilimleri Dergisi, 7(1), 193-206.

İzzet ERDEM.(2020).Koronavirüse (Covid-19) Karşı Türkiye'nin Karantina ve Tedbir Politikaları. Turkish Studies 15(4), 377-388. http://dx.doi.org/10.7827/TurkishStudies.43703

Karayol, M., Turhan, M. Ö., Ünver, R., Ergenekon, B. (2020). Fitness salonlarını kullanan bireylerin müşteri memnuniyet durumlarının incelenmesi, Turkish Studies - Social, 15(3), 1261- 1274.

Küçük, V., ve Koç, H. (2004). Psiko-sosyal gelişim süreci içerisinde insan ve spor ilişkisi. Dumlupınar Üniversitesi Sosyal Bilimler Dergisi. 9(1), 211-223.

Küçükkömürler, S. (2017). Belirsizliğin Psikolojik Etkileri. Nesne-Psikoloji Dergisi, 5(10), 329344.

Saricam, H., Akın, A., Akın, Ü., \& İlbay, A. B. (2014). Motivasyonel kararlılık ölçeğinin Türkçe formu: Geçerlik ve güvenirlik çalışması. Turkish Journal of Education, 3(1), 60-69.

Sarıçam, H., Erguvan, F. M., Akın, A., \& Akça, M. Ş. (2014). Belirsizliğe tahammülsüzlük ölçeği (BTÖ-12) Türkçe formu: Geçerlik ve güvenirlik çalışması. Route Educational and Social Science Journal, 1(3), 148-157.

Scheiner, B. (2020). COVID-19'u kim üretti? Aşısı ne zaman bulunacak?.. Prof. Dr. Sait Yılmaz 25 Mart 2020 Giriş. Policy.

Surveillances, V. (2020). The epidemiological characteristics of an outbreak of 2019 novel coronavirus diseases (COVID-19)—China, 2020. China CDC Weekly, 2(8), 113-122.

Tekin, E. COVID-19 Kaygısının Motivasyon Üzerindeki Etkisi: Z Kuşağı Üzerine Bir Araştırma. TurkishStudies, 15(4), http://dx.doi.org/10.7827/TurkishStudies.440700

Üstün, Ç., Özçiftçi, S. (2020). COVID-19 Pandemisinin Sosyal Yaşam ve Etik Düzlem Üzerine Etkileri: Bir Değerlendirme Çalışması. Anatolian Clinic the Journal of Medical Sciences, 25 (Special Issue on COVID 19), 142-153. http://dx.doi.org/10.21673/anadoluklin.721864

Yıldız, A. B., Gülșen, D. B. A., \& Yılmaz, B. (2015). Sporcuların optimal performans duygu durumunun yaşam tatminleri üzerindeki etkisi. Niğde Beden Egitimi ve Spor Bilimleri Dergisi, vol.9, 58-64. 